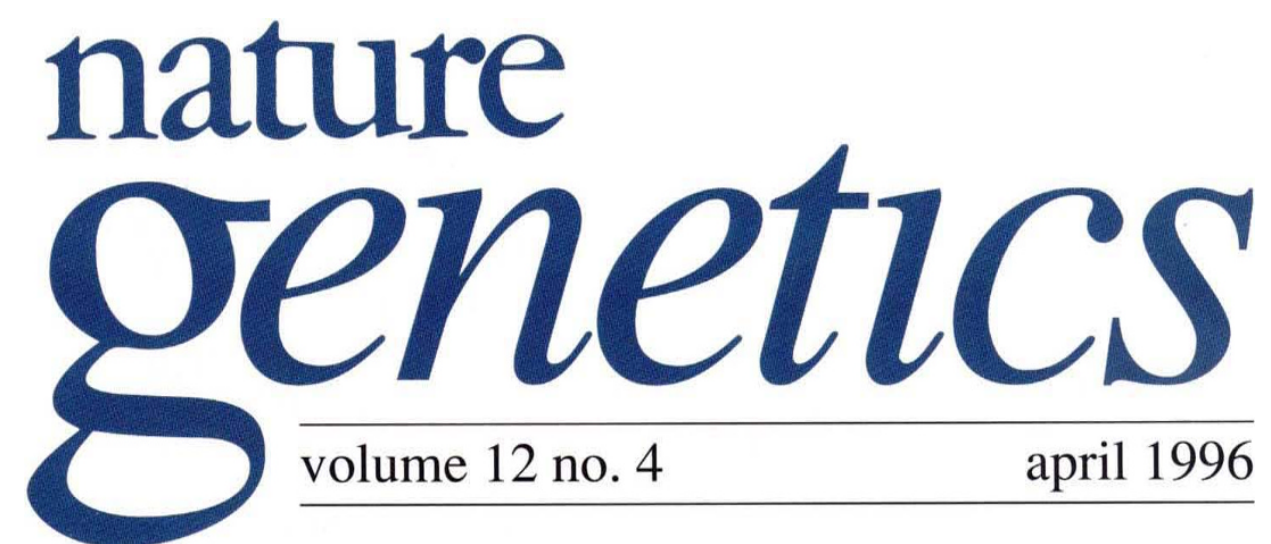

\title{
Romanovs find closure in DNA
}

Two years ago, the heavy Italian marble top was lifted off the coffin in St. Petersburg of Grand Duke Georgij Romanov, the 28-year-old brother of Tsar Nicholas II, who died of tuberculosis in 1899. It was yet another dramatic event in the quest to resolve the bitter controversy surrounding the murdered last tsar and his family, whose grave was discovered in 1991. Any lingering doubts from the ealier genetic analysis of the remains ${ }^{1}$ will be dispelled by the investigation of the grand duke's DNA by Ivanov et al. ${ }^{2}$ appearing on page 417 .

Almost 300 years of Romanov rule ended in 1917, culminating in the Bolshevik uprising. The following year, Nicholas II and his family were imprisoned in the Ipatiev House in Yekaterinburg, Siberia. On the night of July 16, Nicholas, Empress Alexandra, their five children - Olga, Tatiana, Marie, Anastasia and Alexei - their physician and three servants were executed by a firing squad, a hail of bullets ricochet-

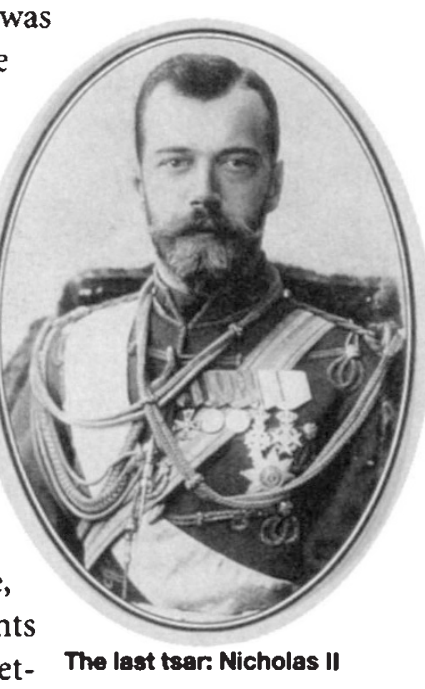
ing off the grand duchesses' jewel-laden corsets ${ }^{3}$. The local newspaper proclaimed that Nicholas had been "shot without bourgeois formalities but in accordance with our new democratic principles." 3

Six months later, a Russian investigator named Nicholas Sokolov recovered valuable pieces of physical evidence from the probable grave site, but found no skeletons. His conclusion that the bodies had been doused in sulphuric acid, butchered and burned to ashes was seldom questioned during 70 years of communist rule. But in April 1989, the Moscow News published an exclusive interview with filmmaker Geli Ryabov, who announced that he knew where the Romanovs were buried. Ryabov and geologist Alexander Avdonin had actually located the grave ten years earlier, five miles from the Sokolov site. Working from photographs and the Kremlin report of Yakov Yurovsky, the executioners' leader, they had retrieved three skulls, only to return them fearfully to the ground the following year.

In July 1991, President Boris Yeltsin authorized the exhumation at Yekaterinburg. Almost 1,000 bone fragments were assembled into five female and four male skeletons. That meant that two of the deceased were missing, consistent with Yurovsky's account that he had burned two of the bodies (those of Alexei and a female). But there was disagreement about which bodies were present. Using photographic 


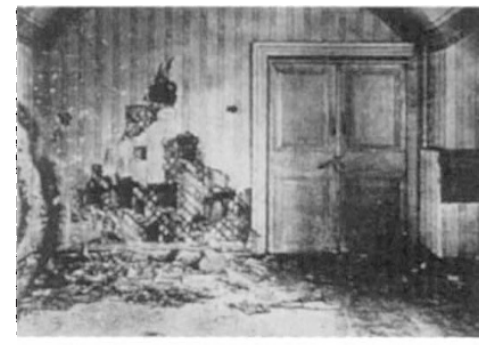

Ipatiev House: site of the atrocity

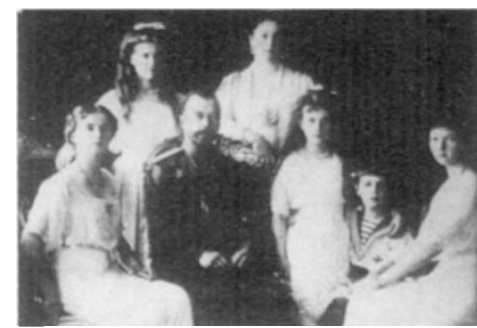

The Romanovs photographed in 1914: (from left to right) Olga, Marie, Nicholas, Alexandra, Anastasia, Alexei and Tatiana
1. Gill, P. Nature Genet. 6, 130-135 (1994).

2. Ivanov, P. et al. Nature Genet. 12, 417-420 (1996).

3. Massie, R.K. The Romanovs: The Last Chapter (Random House, Now York, 1995). 4. Ginther, C., Issel-Tarver, L. \& King, M.-C.
Nature Genet. 2, 135-138(1992).

5. Gill, P. et al. Nature Genet. 9, 9-10 (1995). superimposition, Russian scientists concluded that the tsarevich and Marie were missing. However, an invited American forensic team, led by William Maples of the University of Florida, analysing the dental and bone specimens, believed that the missing grand duchess was Anastasia. At a conference the following summer, a Russian expert on DNA fingerprinting, Pavel Ivanov, announced that DNA tests on the bones would be conducted in collaboration with Peter Gill, at the British Forensic Science Service. On 15 September 1992, Ivanov was welcomed at Heathrow Airport by a $\mathrm{BBC}$ television director, who had hired a funeral hearse because he felt it was 'inappropriate to carry the Russian Imperial family in the boot of my Volvo.'

Gill performed nuclear and mitochondrial $(\mathrm{mt})$ DNA tests on the nine bone samples $^{1}$. Five of the bodies were clearly related, and three were female siblings. Furthermore, a sample of maternally inherited mtDNA suspected to belong to Alexandra matched a sample provided by her grandnephew, the Duke of Edinburgh. But finding a reference sample for Nicholas was more difficult. Ivanov's suggestion to exhume Grand Duke Georgij at that time was financially and politically inconceivable; a swatch from a bloody handkerchief kept in a Japanese museum was too contaminated; and the tsar's nephew, Tikhon Kulikovsky, refused to cooperate, citing his contempt for the British for not offering refuge to his uncle's family after the revolution. But eventually, two more distant maternal relatives, Xenia Sfiri and the Duke of Fife, agreed to help.

Position 16169: As expected, the mtDNA sequences of the tsar's two relatives were identical to each other, but where the relatives had a $\mathrm{T}$ at nucleotide 16169 , the bone mtDNA surprisingly had a C. Further analysis revealed a mixture of mtDNAs in the bone differing at this one position - $\mathrm{C}$ accounting for about 70\%. Gill and colleagues thus concluded that the tsar exhibited 'heteroplasmy', and cautiously estimated the probability of the remains belonging to the tsar as being $98.5 \%{ }^{1}$. Their findings "have never been challenged or even mildly criticized, in print or orally, by another DNA scientist," states historian Robert Massie ${ }^{3}$. Moreover, independent confirmation was provided by Cambridge University's Erika Hagelberg. But critics including Maples charged that the discrepancy was likely due to contamination. Maples returned to Yekaterinburg in April 1993, where he was allowed to remove teeth from the skulls and pass them on to MaryClaire King. (King's results have not been published, but she told Nature Genetics that, using a different technique ${ }^{4}$, her group found a convincing match for Alexandra and her grand niece. They also found $\mathrm{C}$ and $\mathrm{T}$ nucleotides at several sites in the DNA allegedly from Nicholas consistent with heteroplasmy, sequence background, or contamination.)

With the Russian Orthodox Church demanding more proof, the exhumation of Grand Duke Georgij finally occurred in July 1994. This time, Ivanov took the bone samples to the Armed Forces Institute of Pathology DNA Identification Laboratory in Maryland, where remarkably, the same heteroplasmy provided compelling evidence favoring the identification of 'Tsar Nicholas. Grand Duke Georgij's mtDNA exhibits a similar rare mixture of $\mathrm{C}$ and $\mathrm{T}$ at position 16169 - the first time that heteroplasmy has been applied in human identification. Combining the DNA sequence identity, the rarity of heteroplasmy and the established link between Alexandra and the Duke of Edinburgh, Ivanov et al. calculate a likelihood ratio for the remains' authenticity in excess of 100 million (ref. 2) - not including the powerful anthropological and forensic evidence!

At last, the great mystery of the last tsar can be laid to rest. The same is now warranted for his family's remains, although further political and religious wrangling appears inevitable. Some people still might not accept the verdict while two bodies remain missing, even though the case for Anna Anderson, who claimed to be Anastasia, was dismissed by DNA analysis from several groups ${ }^{5}$. Clues to their identities and whereabouts might exist among the relics gathered by Sokolov, including a severed finger and bottles of congealed fat, now said to be held by the Russian Orthodox Church Abroad. However, this should not detract from the resolution of the Romanov saga, or the power of genetic analysis to close one of the most astounding historical mysteries of this century.

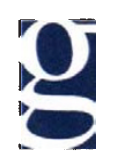

